\title{
VOLDEMORT E BOLSONARO: DIÁLOGO ENTRE ARTE, MÍDIA E POLITICA
}

\section{VOLDEMORT AND BOLSONARO: DIALOGUE BETWEEN ART, MEDIA AND POLITICS}

\author{
Luciane de PAULA ${ }^{1}$ \\ Giovana Cristina de MOURA²
}

Resumo: O Brasil está regido por um governo marcado por uma tendência totalitária historicamente arquitetada desde o integralismo, com encaminhamento que pode ser entendido como neonazifacista, calcado na intolerância. Na saga Harry Potter $(H P)$, as marcas da política vilanesca de Voldemort refletem e refratam as do atual governo brasileiro. O objetivo deste artigo é pensar sobre as simetrias entre vida e arte, semiotizadas por Voldemort e Bolsonaro, além de verificar como essa correlação se tornou debate na comunidade de fãs de $H P$, com relação à associação da obra à política. O método adotado é o dialéticodialógico bakhtiniano. As concepções mobilizadas são: diálogo, enunciado, vozes sociais, reflexo e refração, forças centrípetas e centrífugas, arte e vida. Algumas respostas dos fãs de $H P$ a um manifesto de repúdio à candidatura de Bolsonaro à presidência da República em 2018, postado no maior portal da comunidade no Brasil, o Potterish, em cotejo com declarações do Presidente, compõem esta reflexão, dada a repercussão do evento à época. Os resultados confirmam o pressuposto de que a arte é semeada e nutre a vida, ao menos, é o que ocorre entre Voldemort e Bolsonaro, conforme o próprio manifesto do Potterish.

Palavras-chave: Harry Potter. Círculo de Bakhtin. Enunciado. Diálogo. Ideologia.

\begin{abstract}
Brazil is ruled by a government marked by a totalitarian tendency historically architected since integralism, with a direction that can be understood as neo-nazifascism, based on intolerance. In the Harry Potter (HP) saga, marks of Voldemort's villainous politics reflect and refract the current Brazilian government. The purpose of this article is to reflect on the symmetries between life and art, semiotized by Voldemort and Bolsonaro, as well as to verify how this correlation became possible for the debate in the community of $H P$ fans, concerning the association of the work with politics. The method adopted is the Bakhtinian dialectical-dialogic. The conceptions mobilized are dialogue, utterance, social voices, reflection and refraction, centripetal and centrifugal forces, art, and life. Some responses from $H P$ fans to a manifesto of repudiation of Bolsonaro's candidacy for the presidency of the Republic in 2018, posted on the largest community portal in Brazil, Potterish, in comparison with statements by the President, composes this reflection, given the event's repercussion at the time. The results confirm the assumption that art is sown and nourishes life, at least, that is what happens between Voldemort and Bolsonaro, according to Potterish's manifest.
\end{abstract}

Keywords: Harry Potter. Bakhtin Circle. Utterance. Dialogue. Ideology.

1 Universidade Estadual Paulista "Júlio de Mesquita Filho" (UNESP), Assis, São Paulo, Brasil;
lucianedepaula1@gmail.com; http://orcid.org/0000-0003-1727-0376

2 Universidade Estadual Paulista "Júlio de Mesquita Filho" (UNESP), Araraquara, São Paulo, Brasil; giovana_lutecia@hotmail.com; https://orcid.org/0000-0001-5968-2315 
- Voldemort e Bolsonaro: diálogo entre arte, mídia e política

\section{Introdução}

A saga Harry Potter $(H P)^{3}$ é um enunciado estético, como todo enunciado, ancorado no solo social (o plano da vida), que semiotiza temáticas polêmicas, como regimes políticos totalitários, racismo, questões de gênero e classe, por exemplo.

A saga divide as personagens em grupos que representam valores colocados como "bem" e "mal", separados em casas e subgrupos. Dentre eles, dois se destacam: um como representante de ações totalitárias, de certa forma, até nazistas (dada a questão da

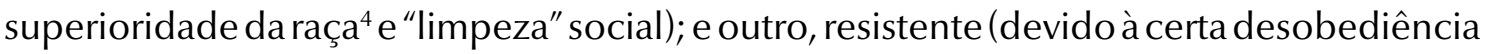
civil). Esses grupos são personificados, respectivamente, por Voldemort e Harry Potter.

De acordo com os estudos bakhtinianos, que fundamentam esta reflexão, a arte reflete e refrata a realidade (VOLÓCHINOV, 2019) experienciada pelos sujeitos ${ }^{5}$ na interação, de forma dialógica, responsiva e responsável (BAKHTIN, 2010). Para essa perspectiva, a arte não é neutra e não pode ser apartada do solo social, de onde parte e para o qual se volta, pois ela, um ato de linguagem com determinado acabamento (o estético), é ideológica e semiotiza juízos de valor, consonantes e dissonantes, uma vez que, como discurso, caracteriza-se como arena/palco ${ }^{6}$ onde se digladiam vozes sociais de valorações contrárias (VOLÓCHINOV, 2017).

Em 2018, período eleitoral presidencial no Brasil, posts associaram a saga, sobretudo o vilão, Lorde Voldemort, ao então candidato, Jair Bolsonaro, de maneira recorrente e geraram debate e repercussão nas mídias sociais, especialmente no Facebook, entre os fãs de HP. No levantamento previamente coletado, percebeu-se que uma parcela dos fãs desaprova tal associação e defende que as fanpages têm perdido o foco ou que HP não é

\footnotetext{
3 Para tratar de alguns aspectos de Harry Potter, considerou-se as produções literária (ROWLING, 2015) e fílmicas (WARNER, 2001, 2002, 2004, 2005, 2007, 2009, 2010, 2011).

4 Como estudam Paula e Siani (2020b), em "O sangue puro em Harry Potter e seus ecos dialógicos eugênicos".

5 Entende-se, aqui, Bolsonaro e Voldemort como sujeitos do ponto de vista da linguagem, como figuras públicas, "personagens", representantes de determinadas vozes sociais e não pessoas empíricas. Afinal, o sujeito, como noção filosófica bakhtiniana, é um ser de linguagem (BAKHTIN, 2019) que reflete e refrata o homem, semiotizando-o com determinado acabamento enunciativo (BAKHTIN/VOLOCHÍNOV, 2019). Assim, o uso desse conceito não se volta a uma pessoa, mas sim à construção de dada pessoa pela e na linguagem.

6 Ainda que na tradução do Marxismo e Filosofia da Linguagem usada (VOLÓCHINOV, 2017), o termo que caracteriza "discurso" seja "palco", o signo "arena", como utilizado na tradução anterior, feita a partir da versão francesa, semiotiza melhor a noção bakhtiniana, uma vez que remete a embate de vozes sociais e luta de forças. Por isso, a preferência pelo uso de arena/palco, para contemplar e ser fiel à tradução do russo (palco) e à do francês (arena). A utilização dupla é uma forma de contemplar a noção de campo de forças, pela perspectiva das autoras, mais adequada ao que compreendem da filosofia bakhtiniana e da concepção de Volóchinov.
} 
uma obra política e que tal comparação deve acabar. Já outra parcela questiona aqueles que se autodenominam "apolíticos" e afirma que eles "não entenderam nada da obra", pois defendem que Bolsonaro se aproxima do vilão da saga e apresentam simetrias entre Voldemort e Bolsonaro.

A característica política que mais aproxima Bolsonaro de Voldemort é a "pureza" como fortaleza e superioridade, valores enaltecidos em regimes eugenistas ${ }^{7}$, conforme Hobsbawn e Santarrita (1995), Diwan (2007) e Black (2003). A expressão "sangue ruim"8 é um insulto abominável no mundo de $H P$, que reflete e refrata a voz nazifascista. Bolsonaro e diversos de seus apoiadores defendem a Ditadura e pedem intervenção militar com instauração do Al-5 no país, com o pretexto de "limpá-lo" /livrá-lo" de um "comunismo" no qual acreditam. Desejam cerceamento, perseguição, tortura e morte por intolerância à diferença, e essas atitudes não são muito diferentes daquelas usadas pelo vilão de $H P$ e seu "exército" (assim chamados, na saga, os seguidores de Voldemort). Daí, a importância de se analisar as axiologias semiotizadas pelo vilão, em diálogo com as vozes assumidas em declarações públicas por Bolsonaro e como elas aparecem no debate entre os potterheads ${ }^{9}$, tendo como foco as manifestações de apoio e repúdio a Bolsonaro, no manifesto de maior repercussão, lançado pela e na maior comunidade de fãs de HP no Brasil, a Potterish.

Os insultos, em $H P$, partem de Voldemort e seus seguidores ao se referirem ou dirigirem a Dumbledore, Harry e seus amigos, com feitiços que colocam em prática blasfêmias e planos. Na política, Bolsonaro, sua equipe e alguns eleitores, muitas vezes, calcados em fake news (hoje, como noticiado por diversos jornais, de diferentes

7 Para aprofundamento sobre a eugenia e o nazifascismo na relação com a linguagem e os atos de Bolsonaro, sugere-se a leitura de Paula e Lopes (2020). Este artigo cita diversas publicações de Paula com diversas coautorias porque os resultados de cada estudo se relacionam com a pesquisa geral maior, por ela desenvolvida. Os objetos são distintos, as temáticas se relacionam e, como a noção de enunciado, cada artigo é único e elo na corrente discursiva de todo o Grupo. Daí, a importância de alinhavar os textos e as pesquisas, referenciando-as.

8 Termo utilizado na saga Harry Potter como um insulto grave que não deve ser feito e se refere à "raça impura". No contexto da obra, a "impureza" é composta por: bruxos mestiços, nascidos trouxas (quando apenas um dos pais é bruxo e o outro, não; ou quando nenhum dos pais é bruxo), abortos (assim chamados, pois considerados uma "aberração", já que filhos de pais bruxos, que não desenvolvem magia) e criaturas mágicas (elfos domésticos, centauros, duendes e animais mágicos diversos). Para ler sobre a análise desse termo em diálogo com a noção de eugenia e os discursos de Bolsonaro, ler Paula e Siani (2020b).

9 Termo usado no fandom (como é conhecido o universo dos fãs) pela síncrese do sobrenome no herói da saga ("Potter") com o signo em inglês "head", que significa cabeça. Um potterhead é um fã de $H P$, que tem o universo de $H P$ em sua mente (livros e filmes, em detalhes). Um consumidor voraz da saga, que realiza quizzes, listas de preferências (top 10, por exemplo), testes para saber a que casa pertence etc. O fandom de HP é o segundo maior do mundo. No Brasil, ele é o maior. Esse também é um critério (quantitativo) para se pensar sobre essa comunidade de sujeitos, composta, majoritariamente, por jovens e crianças (faixa etária de 10 a 30 anos). Por isso, este artigo estuda as valorações e repercussões sociais da saga relacionada à esfera política. 
- Voldemort e Bolsonaro: diálogo entre arte, mídia e política

perspectivas, há denúncias, com comprovações averiguadas pela "CPMI das Fake News", acerca de um "gabinete do ódio", como ficou conhecido um espaço no Palácio do Planalto, destinado à produção e circulação de fake news por uma equipe contratada pelo próprio Governo e gerenciada pelo Vereador Carlos Bolsonaro), insultam quem pensa diferente (e estigmatizam todos como "comunistas", "petistas" e "petralhas" - signos que significam, para eles, as piores ofensas) com xingamentos (lexemas de baixo calão), gestos (armas com as mãos e obscenidades), ameaças e chegam ao extremo da violência física. Entre os fãs de $H P$, no Potterish, a estratégia do lamento e da ameaça, mais do que o insulto, foi a encontrada, calcada na exclusão (deixar de ser seguidor/fã do portal/página). Talvez isso ocorra porque o Facebook não permite determinados mecanismos discursivos e porque dados comportamentos podem ser denunciados, com postagens bloqueadas e perfis penalizados.

Nos romances e filmes de $H P$, os bruxos "sangue ruim" são considerados por alguns "sangues puros" como uma "raça" inferior que, pela miscigenação, não merecem pertencer ou serem aceitos na sociedade bruxa. Voldemort, quando desafiado, assume uma postura violenta, e manipula, tortura e mata por prazer. No plano da vida, diversos são os insultos de Bolsonaro (e sua equipe) a personalidades distintas: o educador Paulo Freire foi chamado de "energúmeno" por ele; a ativista Greta Thunberg, de "pirralha".

A fim de analisar como ocorre a relação entre arte e vida, ficção e realidade, neste caso, para mostrar que são vértices indissociáveis, este trabalho adota o que Paula, Figueiredo e Paula (2011) denominam como método dialético-dialógico ao se referirem ao método bakhtiniano. Os posts selecionados fazem parte da página Potterish, escolhida por ser a que apresentou a polêmica entre os fãs de maneira contundente por ter lançado um manifesto ${ }^{10}$ contra alguém com um discurso semelhante ao do vilão da saga. O embate que se seguiu em decorrência desse manifesto expressou vozes existentes em outras esferas (como a política), revelando o quanto as forças centrípetas (centralizadoras e com tendência à homogeneização e à dominação) e centrífugas (dispersivas, mais heterogêneas) agem nos sujeitos.

Na perspectiva bakhtiniana, o enunciado é responsivo, responsável, ético e não é acabado (no sentido de ter um encerramento do diálogo), ainda que se constitua por seu acabamento ou configuração formal (no caso de $H P$, estético; no caso dos posts, de maneira cotidiana). As dicotomias "bem" e "mal", "direita" e "esquerda", "herói" e "vilão", como tantas outras, ganham vida nos enunciados, que são atos de linguagem e

10 O manifesto está disponível em: https://potterish.com/aquele-que-nao-deve-ser-votado/. Pelo espaço limitado deste artigo, não será reproduzido na íntegra no corpo do texto. 
revelam vozes sociais. O embate entre os fãs de $H P$ acerca da relação entre Voldemort e Bolsonaro, mais do que uma discussão sobre a obra ou sobre o discurso estético, revela posicionamentos políticos, expressos pelas valorações acerca do papel da arte e sua relação com a sociedade.

A partir do coletado, há, de um lado, os fãs que, desde o período eleitoral, têm apontado simetrias entre Voldemort e Bolsonaro, ao que se refere a um discurso de "pureza do sangue" que, cada um ao seu modo (Bolsonaro e Voldemort), legitima e viabiliza a violência contra as minorias, sobretudo contra mulheres, membros da comunidade LGBTQIA+, pessoas de etnias não brancas etc; de outro, há os fãs que acusam as páginas que associam a ficção a Bolsonaro de terem "perdido o foco" ou de serem páginas "esquerdistas".

O embate entre apoio, conivência ou resistência a um governo com traços próximos ao que ocorre em $H P$ (em que há desaparecimentos e mortes; torturas e opressão; liberdade de expressão extinta; censura e manipulação midiática) é um dos traços valorativos constitutivos das vozes e dos valores expressos no objeto analisado.

Este artigo apresenta a teoria conforme empreende a análise, sem uma seção específica separada, pois a utiliza para, de fato, fundamentar a reflexão realizada.

\section{Sujeitos da arte (e) da vida}

Os estudos bakhtinianos concebem o enunciado, ao mesmo tempo, como ato singular e elo na cadeia da existência (VOLÓCHINOV, 2017). Para o Círculo, o signo é ideológico e essa é sua "revolução" (PONZIO, 2016) perspectiva. O discurso literário não é diferente de outros, pois é constituído por signos e não está isento de valores sociais. A arte é composta por elementos existentes na vida e se caracteriza como reflexo e refração dela, com acabamento estético (BAKHTIN, 2014). Nesse sentido, a obra literária (não restrita ao romance), a partir das situações narradas, configura um debate ideológico (PAULA; SIANI, 2019), histórico, uma vez que diversas vozes sociais ressoam no todo da obra por meio das valorações construídas. No caso de $H P$, Paula e Siani (2019, p. 51) reiteram que a estrutura de romanesca reflete e refrata uma estrutura de poder pautada nas imbricações

[...][verbo?] de classe/grupo, gênero e raça, vinculados ao que é denominado pelo senso comum de "bem" e "mal". A defesa de um desses lados-valores pela maneira como a narrativa é arquitetada pela autora-criadora revela seu posicionamento a dada voz, fortalecida a ponto de lutar contra tudo e todos 
- Voldemort e Bolsonaro: diálogo entre arte, mídia e política

e vencer até a morte. Isso produz um sentimento de fidúcia na mudança, a esperança de que é possível, mesmo com discriminação e preconceito, perseguição e punições as mais diversas, num sistema perverso e autoritário, hierárquico e fechado, abrir brechas, a fim de subvertê-lo.

Voldemort, no plano da arte, e Bolsonaro, no plano da vida, possuem um discurso que, de maneira dialético-dialógica (PAULA; FIGUEIREDO; PAULA, 2011), os aproxima: os dois possuem formas de governar que os conectam e isso fez (e ainda faz) com que os fãs se posicionem no meio digital sobre suas visões de mundo. Ambos os sujeitos defendem, cada um a seu modo (já que o enunciado é situado, único e irrepetível), o discurso da "pureza", tanto pela maneira de agir quanto pela maneira de tratar e se referir às pessoas, com insultos (violência simbólica e verbal) e outros tipos de agressões (gestuais e físicas, por exemplo).

No caso de Voldemort, os insultos se voltam, especificamente, aos "sangue ruim", às classes e grupos desprivilegiados econômica, política e socialmente.

No caso de Bolsonaro, além de pessoas que defendem os direitos humanos, aguçam a criticidade, a heterogeneidade e as minorias (todos denominados, como já mencionado, como "esquerdistas", "comunistas", "petistas" e "petralhas"), os insultos" se centram em:

- negros, índios e demais etnias [como, por exemplo: "Alguém já viu um japonês pedindo esmola por aí? Porque é uma raça que tem vergonha na cara. Não é igual essa raça que tá aí embaixo ou como uma minoria tá ruminando aqui do lado (referindo-se a manifestantes contrários à sua fala)"12 e "[...] o afrodescendente mais leve lá pesava sete arrobas. Não fazem nada! Eu acho que nem para procriador eles servem mais"];

- mulheres [“Ô Preta (voltando-se a Preta Gil), eu não vou discutir promiscuidade com quem quer que seja. Eu não corro esse risco (de terum filho homossexual) porque meus filhos foram muito bem educados e não viveram em ambientes como lamentavelmente é o teu", "Foram quatro (filhos) homens, a quinta eu dei uma fraquejada, veio uma mulher",

11 Fonte: declarações publicadas em diversos jornais (como a Folha de S.Paulo, O Estado de S. Paulo, G1 e Uol) e revistas (dentre elas, a Carta Capital, Revista Piauí, Fórum e Veja), canais (YouTube, como o da Lilia Schwarcz, O Historiador, 247 e Boitempo, entre outros) e redes sociais (Facebook, Instagram e Twitter).

12 Todas as citações de pronunciamentos de Bolsonaro foram coletadas da Carta Capital (https://www. cartacapital.com.br/politica/bolsonaro-em-25-frases-polemicas/) e confirmados na Folha de S.Paulo (https://bit.ly/3cs8zjJ) e na página oficial do Twitter de Jair Bolsonaro (https://twitter.com/jairbolsonaro?ref_ src=twsrc\%5Egoogle\%7Ctwcamp\%5Eserp\%7Ctwgr\%5Eauthor). Todas foram acessadas em 17 de abril de 2020, ainda que se refiram a declarações de 2017 a 2019. 
"Ela não merece (ser estuprada) porque ela é muito ruim, porque ela é muito feia, não faz meu gênero, jamais a estupraria. Eu não sou estuprador, mas, se fosse, não iria estuprar porque não merece", "Não é questão de gênero. Tem que botar quem dê conta do recado. Se botar as mulheres vou ter que indicar quantos afrodescendentes?" (sobre o número de mulheres nos ministérios de seu governo), "Por isso o cara paga menos para a mulher (porque ela engravida)" e "Ela (a jornalista Patrícia Campos Mello, do jornal Folha de S.Paulo) queria o furo. Ela queria dar o furo (com gesto) a qualquer preço contra mim"];

- LGBTQIA+ [“O filho começa a ficar assim meio gayzinho, leva um coro ele muda o comportamento dele. Tá certo? Já ouvi de alguns aqui, olha, ainda bem que levei umas palmadas, meu pai me ensinou a ser homem", "Para mim é a morte. Digo mais: (ao se referir à possibilidade de ter um filho homossexual) prefiro que morra num acidente do que apareça com um bigodudo por aí. Para mim ele vai ter morrido mesmo", "Não vou combater nem discriminar, mas, se eu vir dois homens se beijando na rua, vou bater", "Não existe homofobia no Brasil. A maioria dos que morrem, 90\% dos homossexuais que morrem, morre em locais de consumo de drogas, em local de prostituição, ou executado pelo próprio parceiro" e "90\% desses meninos adotados vão ser homossexuais e vão ser garotos de programa com toda certeza desse casal (LGBTQ+)];

- jornalistas ["se algum idiota (se referindo aos jornalistas) vier falar comigo sobre misoginia, homofobia, racismo, 'baitolismo', eu não vou responder sobre isso", "Você pretende se casar comigo um dia? Não seja preconceituoso! Você, você não gosta de loiro de olhos azuis? Isso é homofobia, vou te processar por homofobia. Não admito homofobia! Seu homofóbico! Você pretende se casar comigo? Responde!", "Você (voltando-se a um jornalista) tem uma cara de homossexual terrível. Nem por isso eu te acuso de ser homossexual. Se bem que não é crime ser homossexual" e "Porra rapaz (a um jornalista), pergunta para sua mãe o comprovante que ela deu para o seu pai, tá certo? Pelo amor de Deus"];

- professores (“doutrinadores"); e

- estudantes ("idiotas úteis e massa de manobra"), entre outros.

As falas de Bolsonaro legitimam e estimulam a violência contra as minorias seus seguidores e alguns Ministros agem da mesma maneira, com os mesmos grupos de pessoas (eleitores do Presidente, em ocasiões diferentes, chamaram jornalistas de "anta", "abutres", "oportunista", "lixo", entre outros). Não é por acaso que o número de feminicídio, genocídio contra os indígenas e mortes de LGBTQIA+ aumentou significativamente nos primeiros meses do primeiro ano de mandato de Bolsonaro, assim como uma "limpeza" encampada pelo governador do Rio de Janeiro, em ações militares nas favelas da cidade tem acontecido. 
- Voldemort e Bolsonaro: diálogo entre arte, mídia e política

A semelhança entre Voldemort e Bolsonaro também pode ser apontada ao se considerar a defesa a regimes de exceção (como a ditadura, o fascismo e o nazismo, por exemplo), em que as minorias devem ser extintas (como fica claro nas seguintes falas de Bolsonaro: "Vamos fazer o Brasil para as maiorias. As minorias têm que se curvar às maiorias. As minorias se adequam ou simplesmente desaparecem", "Isso não pode continuar existindo. Tudo é coitadismo. Coitado do negro, coitada da mulher, coitado do gay, coitado do nordestino, coitado do piauiense. Vamos acabar com isso") e pelo incentivo à tortura (Voldemort, pelo hábito de utilizar em suas vítimas, para conseguir o que quer, a "maldição cruciatus"; e Bolsonaro por considerar Ustra, o maior torturador brasileiro do período militar, um "herói nacional" e por afirmar, em ocasiões e em momentos diferentes, frases como: "O erro da ditadura foi torturar e não matar", "Ele merecia isso: pau-de-arara. Funciona. Eu sou favorável à tortura. Tu sabe [sic] disso. E o povo é favorável a isso também", "Através do voto você não vai mudar nada nesse país, nada, absolutamente nada! Só vai mudar, infelizmente, se um dia nós partirmos para uma guerra civil aqui dentro, e fazendo o trabalho que o regime militar não fez: matando uns 30 mil, começando com o FHC, não deixar para fora não, matando! Se vai morrer alguns inocentes, tudo bem, tudo quanto é guerra morre inocente", "A atual Constituição garante a intervenção das Forças Armadas para a manutenção da lei e da ordem. Sou a favor, sim, de uma ditadura, de um regime de exceção, desde que este Congresso dê mais um passo rumo ao abismo, que no meu entender está muito próximo", "Vamos fuzilar a petralhada", "Essa turma, se quiser ficar aqui, vai ter que se colocar sob a lei de todos nós. Ou vão para fora ou vão para a cadeia. Esses marginais vermelhos serão banidos de nossa pátria", "[O policial] entra, resolve o problema e, se matar 10, 15 ou 20, com 10 ou 30 tiros cada um, ele tem que ser condecorado, e não processado").

Pensar nessas propostas e nesses atos de Voldemort e Bolsonaro requer uma discussão sobre a noção de tema e significação para compreender o "purismo" idealizado por esses sujeitos, em seus respectivos enunciados. Segundo Volóchinov (2017, p. 229, grifos do autor):

O tema é um complexo sistema dinâmico de signos que tenta se adequar ao momento concreto da formação. O tema é uma reação da consciência em constituição para a formação da existência. A significação é um artefato técnico de realização do tema. Evidentemente, é impossível traçar um limite absoluto e mecânico entre o tema e a significação. Não há tema sem significação, como não há significação sem tema. 
Na arte, todos os considerados por Voldemort como "sangue ruim" são perseguidos, censurados, torturados, e, muitos deles, mortos. O vilão e Bolsonaro são personagens que se conectam pelas valorações que expressam: possuem ambição pelo poder; um "exército" de seguidores responsáveis por controlar a população a partir da reprodução, tanto na ficção quanto na sociedade, de fake news, da intolerância, do insulto, da ameaça e de outras violências para que ela (a população) siga os ideais do seu representante; a sensação de medo e impotência predomina nos dois governos; há o cerceamento da liberdade de ir e vir, assim como da liberdade de expressão é condenada; há censura nas escolas e nos materiais didáticos; desaparecimentos e exílios são frequentes e a mídia é manipulada. Todos esses atos são mediados em razão do signo da "pureza".

Ao que se refere à concepção de signo, Volóchinov (2017, p. 111) afirma que

Uma vez que o signo é criado entre os indivíduos e no âmbito social, é necessário que o objeto também obtenha uma significação interindividual, pois apenas assim ele poderá adquirir uma forma sígnica. Em outras palavras, somente aquilo que adquiriu um valor social poderá entrar no mundo da ideologia, tomar forma e nele consolidar-se. Convencionalizamos chamar esta realidade, que se torna objeto do signo, de tema do signo. Todo signo acabado possui o seu tema. Assim, todo discurso verbal possui o seu tema. Um tema ideológico sempre recebe uma ênfase social. É claro que todas essas ênfases sociais dos temas ideológicos penetram também na consciência individual que, como sabemos, é totalmente ideológica. É como se nesse caso elas se tornassem ênfases individuais, pois a consciência individual une-se de tal modo a elas que parecem pertencer-lhe; sua origem, no entanto, encontra-se fora dela. A ênfase, por si só, é interindividual.

Nesse sentido, o signo "sangue ruim" reflete e refrata não apenas a consciência de Voldemort e Bolsonaro, mas os de seus governos, sustentados, por identificação, de seus seguidores [no plano da arte, os Comensais da Morte; e, no da vida, conforme estuda Oliveira (2020), os bolsominions]. Esses seguidores, a partir do discurso expresso por Voldemort e Bolsonaro, apropriam-se do discurso que engloba o tema "sangue ruim" para ofender, ameaçar e perseguir aqueles considerados inferiores ou diferentes. A "raça pura" (DIWAN, 2007) é semiotizada, na arte, pela disputa de poder entre Voldemort e Harry Potter e pela busca de imortalidade de Voldemort, que age de acordo com seus propósitos, sem ética e de maneira sórdida; e, na vida, pelos atos de líderes políticos como Bolsonaro, uma vez que a intolerância e o autoritarismo seguidos de violência têm crescido em nossa sociedade, tanto no Brasil quanto em outros países, pela manipulação 
- Voldemort e Bolsonaro: diálogo entre arte, mídia e política

de dados pessoais mediada pela tecnologia, que tem alavancado uma onda conservadora de direita em todo o mundo.

A intolerância, o cerceamento e a violência são marcas típicas de governos totalitários. Voldemort e Bolsonaro possuem um discurso marcado pela "pureza" e os que não se enquadram no que eles consideram "mais fortes" são silenciados, punidos e executados. Atos de descaso, perseguição, tortura e morte constituem a prática dos dois sujeitos, expressa por meio da linguagem. Segundo Volóchinov (2017), a linguagem materializa os atos, sendo também, por sua vez, atos de outra natureza, semiótica. No caso estudado, tanto a obra literária quanto os pronunciamentos do presidente e os posts dos fãs de $H P$ sobre a relação entre esses dois sujeitos constroem significações acerca dos posicionamentos em embate.

Num movimento dialético-dialógico (PAULA; FIGUEIREDO; PAULA, 2011), as vozes da superestrutura se chocam com as da infraestrutura, tanto em concordância quanto em discordância, em infindável processo de vir-a-ser, num infinito movimento em espiral, como explicita Marx (2007). Nesse sentido, pode-se dizer que o sujeito de linguagem é comprometido com o mundo que o circunda e que a arte responde à vida, pois nasce e sobrevive nela (BAKHTIN, 2011). O discurso da "pureza" de Voldemort/Bolsonaro expressa valores de governos que se ocupam em cercear discordantes. Agem para a garantia de valores conservadores, para a manutenção do poder, por meio das mídias, da lei e da igreja, que manipulam os sujeitos para que permitam serem governados por quem os silencia. Os sujeitos são constituídos a partir de consciências que estão em constante movimento de reconstrução:

Nenhum signo cultural permanece isolado se for compreendido e ponderado, pois ele passa a fazer parte da unidade da consciência verbalmente formalizada. A consciência sempre saberá encontrar alguma aproximação verbal com o signo cultural. Por isso, em torno de todo o signo ideológico se formam como que círculos crescentes de respostas e ressonâncias verbais. Qualquer refração ideológica da existência em formação, em qualquer material significante que seja, é acompanhada pela refração ideológica na palavra como um fenômeno obrigatoriamente concomitante. A palavra está presente em todo ato de compreensão e em todo ato de interpretação. (VOLOCHíNOV, 2017, p. 101).

Em governos autoritários, os valores refletidos e refratados por essa consciência revelam ideais preconceituosos e intolerantes, por se encontrarem no poder líderes que falam o que comunidades conservadoras desejam ouvir. No Brasil, Bolsonaro é um líder que semiotiza vozes tradicionais com as quais compactua, ora de forma mais velada, ora (na 
maior parte das vezes), aberta. Com seu discurso, ele legitima preconceitos e intolerâncias frente à diferença, o que é sustentado pelo tom emocional-volitivo empregado, tanto por Bolsonaro quanto por Voldemort, em seus pronunciamentos ${ }^{13}$.

Os valores expressos no discurso se caracterizam pela respondibilidade dos sujeitos. Os seguidores das personagens materializam os ideais de seus governos nas mais diversas esferas que dão forma à vida social. O tom emocional-volitivo empregado pelos sujeitos corresponde a valores amparados pela cultura. Cada sujeito se revela a partir de atos que se manifestam na interação. Respondem a contextos a partir de um tom específico para cada acontecimento, de forma singular em cada evento (MEDVIÉDEV, 2012).

As personagens analisadas promovem e prometem, situadas no contexto ao qual se vinculam, uma espécie de "limpeza do mundo". No mundo mágico-bruxo, abortos, trouxas, elfos domésticos, centauros e demais criaturas, bem como os "sangue ruim" e até os "sangue puros" que protegem tais sujeitos são torturados, censurados, oprimidos e vigiados, tanto pela mídia (impressa - o jornal O Profeta Diário) quanto por alguns professores (como Quirino Quirrell e Dolores Umbridge, por exemplo), na escola (Hogwarts) e pelo governo (o Ministério da Magia, via "Comensais da Morte"). No Brasil, desde o segundo turno da campanha presidencial até agora (segundo ano de mandato de Bolsonaro), professores são perseguidos, materiais didáticos e obras diversas com "teor ideológico" são apreendidas, mulheres, negros, indígenas e comunidade LBGTQIA+ sofrem assédios com comentários desrespeitosos e ofensivos, dentre outras formas de intolerância.

Em outras palavras, Bolsonaro e Voldemort refletem e refratam vozes que reforçam certa dominação e esse processo é mediado por signos ideológicos reproduzidos por seus adeptos, tanto na arte quanto na vida, pelos embates expressos nas mídias.

Os Comensais da Morte se apropriam da "Marca Negra", uma tatuagem feita no braço direito dos seguidores de Voldemort e expressa no céu quando praticam um crime. Com ela, o grupo instaura e reforça o medo, pelo alerta marcado na comunidade acerca de seus feitos.

No plano da vida não é diferente. Os bolsominions, uma das alcunhas dos seguidores de Bolsonaro, também possuem marcas caricatas, como estuda Oliveira (2020) e demonstram Paula e Oliveira $(2019,2020)$ : a apropriação da camiseta da seleção brasileira e da bandeira do Brasil como signos ideológicos nacionalistas e o gesto de arma feito

13 Não são descritos aqui os pronunciamentos e outros detalhes de apresentação tanto de Voldemort e da saga de HP quanto de Bolsonaro, devido à extensão do artigo. 
- Voldemort e Bolsonaro: diálogo entre arte, mídia e política

com os dedos são dois deles. Além disso, acreditam no presidente (o "Messias" "enviado por Deus" com a missão de "salvar" o país) e fazem valer seu discurso no cotidiano, por meio das perseguições (a marcas, empresas, escolas, professores, STF, jornalistas, alguns políticos e partidos - especialmente os de esquerda, alguns pensadores - como Paulo Freire, Darwin e Foucault, mulheres, negros, índios e comunidade LGBTQIA+, alguns órgãos de imprensa - como a Folha de S.Paulo, a Globo, a Carta Capital, entre outros), ofensas e ameaças, o que é habitual de, estimulado e validado por Bolsonaro, da mesma maneira que por Voldemort, na saga de $H P$.

Segundo Volóchinov (2017, p. 99):

Cada campo possui seu próprio material ideológico e forma seus próprios signos e símbolos específicos inaplicáveis a outros campos. Nesse caso, o signo é criado por uma função ideológica específica e é inseparável dela. Já a palavra é neutra em relação a qualquer função ideológica específica. Ela pode assumir qualquer função ideológica: científica, estética, moral, religiosa.

O uso do jornalismo, da publicidade e da propaganda, na arte e na vida, colabora com a instituição ideológica para a construção de heróis e vilões, a depender dos interesses dos sujeitos que detêm os meios de produção e dominam a esfera econômica. As mídias em geral instauram medo e/ou devoção na população frente a quem os governa. Governos autoritários têm seus apoiadores (no nazismo alemão, por exemplo, até os judeus, perseguidos, inicialmente, apoiaram as ideias propagadas por Hitler), grupos que sustentam suas ideias e possibilitam a realização de seus intentos (Stálin, Hitler, Salazar, Mussolini, Péron, Pinochet e Vargas são alguns exemplos). O "exército" de Voldemort muito se assemelha aos bolsominions pelos discursos preconceituosos frente àqueles que consideram "sangue ruim" e fazem uso da força física para a garantia dos atos e valores daqueles que servem. Eles são responsáveis por punir, perseguir e aniquilar os diferentes resistentes.

Segundo Bakhtin (2011), a cada enunciação, o sujeito produz e expressa sua perspectiva. Como o mundo tem experienciado uma era conservadora, valores aparentemente superados têm voltado à tona (como o terraplanismo) e aqueles que negam essas axiologias têm sido alvo de comentários racistas, machistas, homofóbicos e puristas.

O processo discursivo toma forma na relação do sujeito-eu com seus outros (PONZIO, 2010, 2018), pois é o outro que instiga respostas e é a esse outro a quem o eu se dirige. Essa relação contorna a consciência e os valores que se revelam na interação, 
uma vez que a consciência é construída a partir e por meio de signos. Os valores se materializam pelas vozes sociais, que refletem e refratam uma lógica em embate no enunciado. Segundo Volóchinov (2017, p. 93),

[...] o signo não é somente uma parte da realidade, mas também reflete e refrata uma outra realidade, sendo por isso mesmo capaz de distorcê-la, ser-lhe fiel, percebê-la de um ponto de vista específico e assim por diante. As categorias de avaliação ideológica (falso, verdadeiro, correto, justo, bom etc.) podem ser aplicadas a qualquer signo. O campo ideológico coincide com o campo dos signos. Eles podem ser igualados. Onde há signo há também ideologia. Tudo o que é ideológico possui significação sígnica.

Os valores que dão forma à consciência pertencem aos domínios sociais e o sujeito é construído pelo processo de embate com a voz do outro. A entonação (vocal) empregada pelo tom do sujeito em cada enunciação (VOLOCHíNOV, 2013) verbal, também é constituída por uma imagem (visual) mental, um elemento inerente à vida. Nesse sentido é que Paula (2017), Paula e Serni (2017) e Paula e Luciano (2020a, 2020b, 2020c, 2020d, 2020e) compreendem a concepção bakhtiniana de linguagem como tridimensional, seja potencial seja explícita.

A vida é modelada pelo enunciado, constituído pela verbivocovisualidade, na interação eu-outro, de maneira situada e cada contexto evoca um tom emocional-volitivo, visto que cada sujeito é único e cada interação, irrepetível. Ações discursivas são carregadas de vozes e tempo-espaço sociais, históricos, políticos, econômicos e culturais. Voldemort e Bolsonaro expressam seus valores em embate com outros. Segundo Volóchinov (2017, p. 93), "os signos também são objetos únicos e materiais e, como foi visto, qualquer objeto da natureza, da tecnologia ou do consumo pode se tornar um signo. Neste caso, porém, ele irá adquirir uma significação que ultrapassa os limites da sua existência particular".

O confronto entre forças centrípetas e centrífugas se encontra na arena aqui estudada: na vida pública de Bolsonaro, inúmeros foram os casos em que o ódio e a intolerância às minorias foram explicitados em seu discurso e esses são os principais argumentos apontados pela oposição, aqui representada pelos fãs favoráveis ao manifesto do Potterish, para não votar nele. Os fãs "apolíticos" também se posicionam frente a esses outros (Bolsonaro, o portal e outros fãs) por não aceitarem a associação de $H P$-Voldemort (da arte) com a política.

Volochínov (2017) entende que a consciência é responsavelmente ativa. Cria-se múltiplas identidades e perspectivas de mundo, tanto pelas que reprimem/oprimem 
- Voldemort e Bolsonaro: diálogo entre arte, mídia e política

quanto pelas que contestam os valores autoritários. Os enunciados estéticos, em suas dimensões (verbivocovisuais), refletem e refratam sujeitos socioculturais de forma responsivo-responsável e conectam as duas personagens à vida política.

\section{Forças centrípetas e centrífugas entre esferas e sujeitos enunciados}

Este estudo se sustenta na concepção de verbivocovisualidade cunhada por Paula (2017), Paula e Serni (2017) e Paula e Luciano (2020a, 2020b, 2020c, 2020d, 2020e). De acordo com os estudiosos, em consonância com os estudos bakhtinianos, a interação humana toma forma a partir das três dimensões da linguagem: a verbal, a vocal e a visual, intrínsecas, seja como potencialidade, seja de maneira expressa no enunciado. Bakhtin (2016) entende que a interação se materializa por meio de diversas manifestações de linguagem: verbal (escrita e oral), vocal (entonação - unida à verbalidade, seja pela prosódia, na oralidade, seja pela pontuação, assonância, aliteração e onomatopeias, na escrita) e visual (gestos, expressões corporais e faciais, focalização de câmeras, cores, figurinos, cenografia, formas, posições etc). Conforme Bakhtin (2016), as esferas da atividade são compostas na e por meio da linguagem. Os modos de utilização da linguagem são os mais diversos e podem explorar as dimensões de maneira multimodal (verbo-vocal, verbo-visual, voco-visual ou verbo-voco-visual) ou não. Todavia, mesmo quando o enunciado não transparece sua composição tridimensional, caracterizandose, aparentemente, como apenas verbal, vocal-sonora ou visual, ele, potencialmente, constitui-se como verbivocovisual, já que a entonação discursiva não se dissocia do verbal (ao contrário, constitui-se nele), assim como uma imagem mental conceitual (visual) que associa o signo ao mundo.

Com esse prisma é que se analisa o manifesto do Potterish, pois, na época das eleições presidenciais de 2018, ele levou uma legião de fãs a se posicionar sobre a associação de HP à política brasileira. As esferas literária, midiática e política se intercambiaram nesse embate. Os fãs podem ser divididos em dois grupos: os que se autointitulam "apolíticos" (mesmo ao se posicionarem contra a página, por meio de ameaças, como, por exemplo "até aqui? descurtindo agora", por acharem que arte nada tem a ver com política e por não quererem discutir questões do teor expresso pelo manifesto; e por se chocarem com fãs de posição oposta) e os fãs favoráveis à associação apresentada no manifesto.

A dialogia entre arte e política ocorre na tensão entre vozes e posicionamentos, em espaço-tempos específicos, pelos signos. Como explica Medviédev (2012, p. 56-57), 
O meio ideológico é a consciência social de uma dada coletividade, realizada, materializada e exteriormente expressa. Essa consciência é determinada pela existência econômica e, por sua vez, determina a consciência individual de cada membro da coletividade. De fato, a consciência individual só pode tornar-se uma consciência quando é realizada nessas formas presentes no meio ideológico: na língua, no gesto convencional, na imagem artística, no mito e assim por diante. O meio ideológico é o meio da consciência. Somente por meio dele e com o seu auxílio a consciência humana abre caminho para o conhecimento e para o domínio da existência socioeconômica e natural. O meio ideológico é sempre dado no seu vir a ser dialético, nele, sempre existem contradições que, uma vez superadas, reaparecem. Mas para cada coletividade, em dada época do seu desenvolvimento histórico, esse meio se manifesta em uma totalidade concreta, singular e única, reunindo em uma síntese viva e imediata a ciência, a arte, a moral e outras ideologias.

O governo sobre o qual esses fãs se posicionam, em concordância ou discordância, revela-se na consciência e se concretiza no enunciado, de maneira responsiva e responsável, pelo embate de vozes e de forças centrípetas e centrífugas. Conforme os estudos de Bakhtin (2018), as forças centrípetas tendem à unificação, cristalização e imposição de uma dada voz social, enquanto as forças centrífugas são dispersivas. Essas forças se retroalimentam, em tensão. O conflito entre essas forças revela relações sociais, no caso, de um grupo de fãs que, junto ao Potterish, lutou contra a eleição de um sujeito que semiotizaria um governo centrípeto (centralizador), em conflito com fãs "apolíticos", que não queriam misturar arte e política, assim como não viam semelhanças entre Voldemort e Bolsonaro. A figura 1 ilustra a postura dos que se dizem "apolíticos" e revela que essa designação é um álibi.

Apesar de todos os fãs da figura 1 tentarem separar a relação arte e política, há uma diferença entre os dois primeiros e os dois últimos comentários. Enquanto os primeiros se posicionam como "apolíticos", o terceiro, sem argumento, deixa de ser fã da página devido ao seu posicionamento e o quarto se assume a favor de Bolsonaro, comparando-o a Harry Potter, o herói-“mito" que sobreviveu (Harry, a um assassinato, a maldição da morte - a avada kedavra - proferida por Voldemort; e Bolsonaro, também, a uma tentativa de atentado, a uma facada). Além disso, o comentário do último fã explicita o antagonismo de seu posicionamento, com o "ele sim" (em resposta ao "\#EleNão" do manifesto) e com a imagem de Bolsonaro rindo com a frase "É melhor JAIR se acostumando". Ainda fica clara a posição de oposição ao PT que, de "Partido dos Trabalhadores", passa a ser designado como "Partido das Trevas", também em alusão a HP. A contradição entre a fala final do 
- Voldemort e Bolsonaro: diálogo entre arte, mídia e política

post ("Não venha misturar minha franquia favorita com política") e os atos do sujeito que, para se posicionar a favor de Bolsonaro, utiliza a saga, revela que a questão não é a "neutralidade" (inexistente), mas sim a discordância com o posicionamento da página, explicitada pelo manifesto lançado.

Figura 1. Os fãs "apolíticos"

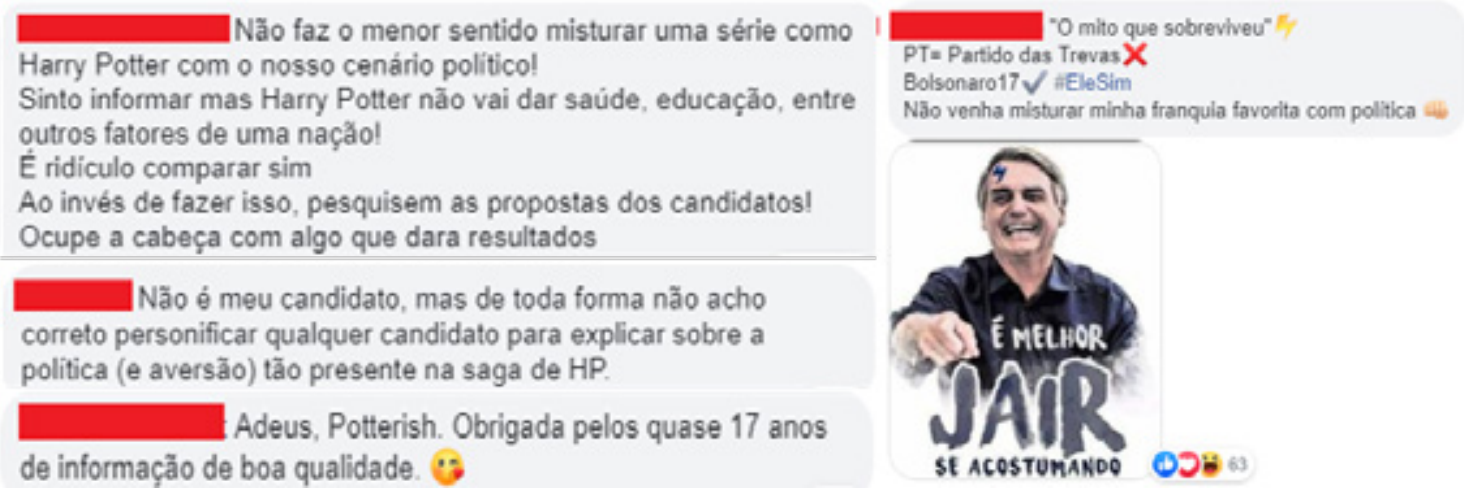

Fonte: Aquele-Que-Não-Deve-Ser-Votado ${ }^{14}$

A relação entre arte e vida, como reflexo e refração de vozes, revela embate entre forças centrípetas (que fazem com que esse discurso ganhe força, não só com o presidente, mas também entre seus seguidores, o que estimula a intolerância e a violência) e centrífugas (resistentes à intolerância). As forças centrífugas, representadas pelos fãs que se posicionaram a favor do manifesto, mostram, pelos comentários, as simetrias entre Bolsonaro e Voldemort. Na saga, o vilão quer livrar o mundo daqueles que considera indignos de pertencerem à comunidade bruxa e quando ascende ao poder os persegue. Bolsonaro declara seu favoritismo à ditadura e à tortura. A partir dessas simetrias, o manifesto e os fãs contrários aos "apolíticos" apresentam trechos das obras para comprovar aos potterheads a relação entre arte e vida, bem como o perigo de alguém como Bolsonaro no poder.

Ao tratar do signo ideológico, Volóchinov (2017, p. 113) afirma que

Justamente aquilo que torna o signo ideológico vivo e mutável faz dele um meio que reflete e refrata a existência. A classe dominante tende a atribuir ao signo ideológico um caráter eterno e superior à luta de classes, apagar ou ocultar o embate das avaliações sociais no seu interior, tornando-o monoacentual. Contudo, assim como Janus, qualquer signo ideológico tem duas faces. Qualquer xingamento vivo pode se tornar um elogio, qualquer verdade viva

142 de outubro 2018. Disponível em: https://www.facebook.com/Potterish/. Acesso em: 06 jan. 2019. 
deve inevitavelmente soar para muitos como uma grande mentira. Essa dialética interna do signo revela-se na sua totalidade apenas em épocas de crises sociais e de mudanças revolucionárias. Em condições normais da vida social, essa contradição contida em todo signo ideológico é incapaz de revelar-se em absoluto, pois na ideologia dominante o signo ideológico é sempre um pouco reacionário, em uma espécie de tentativa de estabilizar o momento anterior do fluxo dialético da formação social, ou seja, de enfatizar a verdade de ontem como se fosse a verdade de hoje.

Os enunciados aqui analisados revelam o embate entre as forças centrípetas e centrífugas no período eleitoral de 2018 e, de maneira dialético-dialógica (PAULA; FIGUEIREDO; PAULA, 2011), os sujeitos refletem e refratam condições específicas das esferas artística, midiática e política. As esferas elaboram os seus tipos relativamente estáveis de enunciados - os gêneros (BAKHTIN, 2016) - e as vozes se revelam na interação, aqui, na tensão entre os fãs favoráveis à associação de Voldemort a Bolsonaro e os "apolíticos". As esferas midiática e política são do plano da vida. Fora dele, a arte inexiste (BAKHTIN, 2011).

Conforme Volochínov (2013), as vozes sociais são produtos da atividade humana que reverberam nos enunciados, no caso, na esfera midiática (aqui representada pela página do Potterish, por fãs que se posicionaram frente à candidatura de Bolsonaro, ao semiotizarem o embate entre forças centrípetas - em consonância com o discurso de Bolsonaro e, consequentemente, compactuaram com a intolerância marcada nele; e centrífugas - o manifesto e os fãs que mobilizaram a obra para estabelecer as assimilações entre o discurso do presidenciável e a saga). Não é só o conteúdo temático que reflete e refrata as vozes, mas também a forma composicional e o estilo (autoral e genérico).

Bakhtin (2011, p. 261-262) afirma que "todos esses três elementos - o conteúdo temático, o estilo, a construção composicional - estão indissoluvelmente ligados no todo do enunciado e são igualmente determinados pela especificidade de um determinado campo da comunicação". Eles se manifestam nas esferas, regidas a partir de produtos ideológicos que semiotizam sujeitos em interação com seus outros: no caso, fãs "apolíticos" e fãs que compactuam com o manifesto se posicionam frente ao discurso em voga. O valor defendido por Voldemort e Bolsonaro é a "superioridade" do ser (bruxo-homem).

Conforme Medviédev (2012), esses produtos são criações construídas nas esferas da atividade humana - semiotizadas, neste estudo, pelas midiática e política. Tais produtos são objetos materiais e partem da realidade que circunda o sujeito. As criações ideológicas possuem sentido e valores internos e externos. Esses produtos inexistem fora 
- Voldemort e Bolsonaro: diálogo entre arte, mídia e política

da concretude. Nesse sentido, Medviédev (2012) reitera que as concepções de mundo dão forma à realidade ideológica quando enunciadas por meio dos signos e dos atos de linguagem.

\section{Aquele-que-não-deve-ser-nomeado/votado: embates sobre Voldemort e Bolsonaro}

As produções midiáticas dão vida às mais diversas discussões (JENKINS, 2006). Segundo Barissa (2019), a saga, desde o seu primeiro livro (Harry Potter e a Pedra Filosofal, 1997), possui grande repercussão em plataformas digitais e os fãs atuam de forma enfática na rede, em páginas voltadas à obra, produzindo até hoje, mesmo após o encerramento da saga, com o oitavo filme da franquia (Harry Potter e as Relíquias da Morte, 2011), os mais diversos enunciados. A pesquisadora aponta que esses fãs se colocam em uma nova posição: a de um leitor que produz, um leitor-autor que valora a obra a partir de suas visões de mundo.

A produção ideológica toma forma na linguagem enunciada. A ideologia do signo modela a sociedade e garante o funcionamento do meio social, pois um determinado valor continua a existir enquanto reflexo e refração que toma forma na interação entre dois ou mais sujeitos. Aqui, no caso, como os fãs responderam aos valores bolsonaristas no período eleitoral de 2018 no Brasil. Arte e vida, de maneira conjunta, revelam o homem enunciado, o sujeito situado social, histórica e culturalmente.

Para os estudos bakhtinianos (BAKHTIN, 2017), a arte parte e semiotiza o solo social e, por isso, constitui-se, arquitetonicamente, como seu reflexo e refração. Ao se considerar a temática política em $H P$, percebe-se que os atos de Voldemort, do início a fim da saga, pautam-se pelo poder autoritário, cerceador, persecutório, discriminador e preconceituoso, o que remete aos pronunciamentos de Bolsonaro. Ao se pensar nas esferas política e midiática, percebe-se a ação dos fãs "apolíticos" em choque com a manifestação dos fãs que enxergam simetria entre o vilão e o candidato, por suas palavras. Volóchinov (2017, p. 101), quanto à noção de palavra, afirma que:

Esse papel excepcional da palavra como um meio da consciência determina o fato de que a palavra acompanha toda a criação ideológica com seu ingrediente indispensável. A palavra acompanha e comenta todo ato ideológico. Os processos de compreensão de qualquer fenômeno ideológico (de um quadro, música, rito, ato) não podem ser realizados sem a participação do discurso interior. Todas as manifestações da criação ideológica, isto é, todos os outros signos não verbais são envolvidos pelo universo verbal, emergem nele e não podem nem ser isolados, nem completamente separados dele. 
Com base nessa concepção, entende-se a conexão arte e vida: Bolsonaro e Voldemort manipulam e controlam as mídias para que essas alienem e conduzam as pessoas a pensarem o quanto eles são heróis em quem devem confiar. Aqueles que não convencem, perseguem, discriminam e oprimem em níveis diversos (desde a censura até a retirada de materiais de "conteúdo ideológico" de circulação, corte de verbas, violência física e simbólica, assim como punição aos diferentes, que resistem e discordam dessas práticas).

Conforme Machado e Gonzatti (2019), na saga Harry Potter, Voldemort faz uso de um feitiço de rastreamento que impossibilita as pessoas dizerem o seu nome. Assim, toda pessoa que use o signo Voldemort (nome criado por ele para si, uma vez que se envergonha do seu nome verdadeiro, Tom Riddle, por pertencer ao seu pai trouxa) é localizada. Devido ao medo do vilão, a comunidade bruxa passou a chamá-lo por outros nomes, sendo os mais recorrentes "Você-Sabe-Quem" e "Aquele-Que-Não-Deve-SerNomeado" - daí, a manchete do manifesto contra Bolsonaro: "Aquele-Que-Não-DeveSer-Votado".

Em razão das semelhanças entre os dois sujeitos, uma parcela expressiva dos fãs passou a se posicionar contra o discurso de ódio voltado a mulheres, pessoas não-brancas e LGBTQIA+ proferido por Bolsonaro. Para isso, esses fãs se apoiaram na narrativa ficcional, utilizando-a como instrumento para a mobilização política.

Ao que concerne à publicação do Potterish, os fãs respondem em concordância e discordância à posição do portal. Alguns dos comentários tratam da postura de Bolsonaro:

Figura 2. Manifestação dos fãs sobre a relação entre os discursos de Voldemort e Bolsonaro

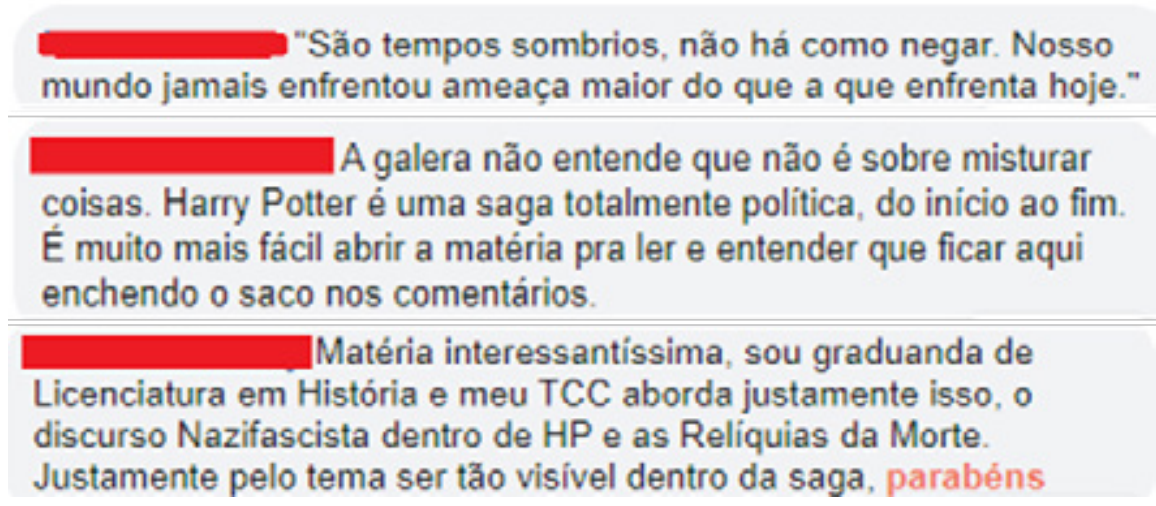

Fonte: Aquele-Que-Não-Deve-Ser-Votado ${ }^{15}$

152 de outubro 2018. Disponível em: https://www.facebook.com/Potterish/. Acesso em: 06 jan. 2019. 
- Voldemort e Bolsonaro: diálogo entre arte, mídia e política

Com base nos estudos de Volóchinov (2017, 2013), aqui explanados, sobre signo ideológico e palavra, pode-se dizer que a política assumida por esses líderes (Voldemort e Bolsonaro) mantém a ideologia conservadora e intolerante no dia a dia, visto que ambos possuem o seu "exército" de seguidores. Esses são responsáveis por, de formas diversas, discriminar, perseguir e punir aqueles que resistem a esses ideais e o fazem por meio de insultos, boicotes e ameaças. Para isso, apropriam-se das mídias, especialmente com fake news, para manipular as pessoas e estimulá-las a defender esses valores. É a isso que os fãs respondem. De acordo com Volóchinov (2017, p. 109), sobre repertório discursivo,

Cada época e cada grupo social possui o seu próprio repertório de formas discursivas da comunicação ideológica cotidiana. Cada grupo de formas homogêneas, ou seja, cada gênero discursivo cotidiano, possui seu próprio conjunto de temas. Existe uma unidade ininterrupta e orgânica entre a forma da comunicação [...], a forma do enunciado [...] e o seu tema.

O repertório não é um fenômeno apenas individual - os valores inexistem fora da interação, pois é ela que os reafirma. Para que os governos existam, é preciso que sujeitos respondam a eles. É contra esse discurso que o manifesto do Potterish toma forma, assim como as respostas dele sucedidas. Voldemort e Bolsonaro se assemelham, como já mencionado, por possuírem uma ideologia de "pureza" parecida. No caso do primeiro, quando ele ascende ao poder, pelo controle do Ministério da Magia ${ }^{16}$, bem como pela manipulação da principal fonte de notícias do mundo mágico, o jornal O Profeta Diário, pois iniciou uma campanha de perseguição contra aqueles que considerava "impuros". Com base em Volóchinov (2017, p. 92) acerca da relação entre instrumento de produção (o jornal) e signo ideológico,

Um instrumento de produção é em si mesmo privado de significação e possui apenas uma utilidade: a de servir para algum objetivo de produção. $\mathrm{O}$ instrumento serve a esse objetivo na qualidade de objeto singular, sem refletir nem substituir nada. No entanto, um instrumento de produção também pode ser transformado em signo ideológico.

Os sujeitos mais atingidos com a política opressora de Voldemort são os chamados "mestiços" ou "nascidos trouxas". Além deles e das criaturas, as pessoas que apoiam essas causas, mesmo sendo "sangue puro", também são perseguidas, consideradas "traidoras do sangue". No plano da vida, não é difícil visualizar essa ideologia da "pureza" e da

16 Governo bruxo. 
"superioridade". Desde as últimas eleições, muitos brasileiros têm proferido discursos intolerantes. Uma voz se libertou: a do nazifascismo, antes, inibida e, agora, estimulada.

Bolsonaro, em diversas entrevistas ao longo dos 30 anos que atua na política brasileira, mostrou-se machista, racista, homofóbico e intolerante. Ao ganhar as eleições, comentários desse teor, que representam, portanto, essa voz, advindos, principalmente, do seu eleitorado, a cada dia, de maneira mais frequente, são direcionados a mulheres, professores, jornalistas, imigrantes, indígenas, negros, LGBTQIA+, entre outros.

De acordo com Volóchinov (2017), as palavras atuam como uma manifestação efetiva da produção de sentidos. As vozes sociais (repletas de juízos de valor), expressas por sujeitos em interação viva, refletem e refratam um embate ideológico, visto que os valores conservadores e resistentes se digladiam no cotidiano, por meio da tensão entre as forças centrípetas e centrífugas, colocando em contato infra e superestrutura.

No caso do manifesto do Potterish, como mostrado na Figura 2, parte dos fãs enxerga e debate acerca das semelhanças entre os dois líderes, em diálogo, outra parcela se manifesta contra a posição do portal. Muitos, como na Figura 3, argumentam com ameaça (de "descurtir a página") e lamentos emotivo-volitivos (expressando tristeza e decepção), uma vez que ela tem propagado, do ponto de vista deles, o discurso de um partido específico (em alusão ao PT), o que é típico no discurso dos adeptos seguidores de Bolsonaro:

Figura 3. Fãs contrários à associação de Harry Potter com a política brasileira

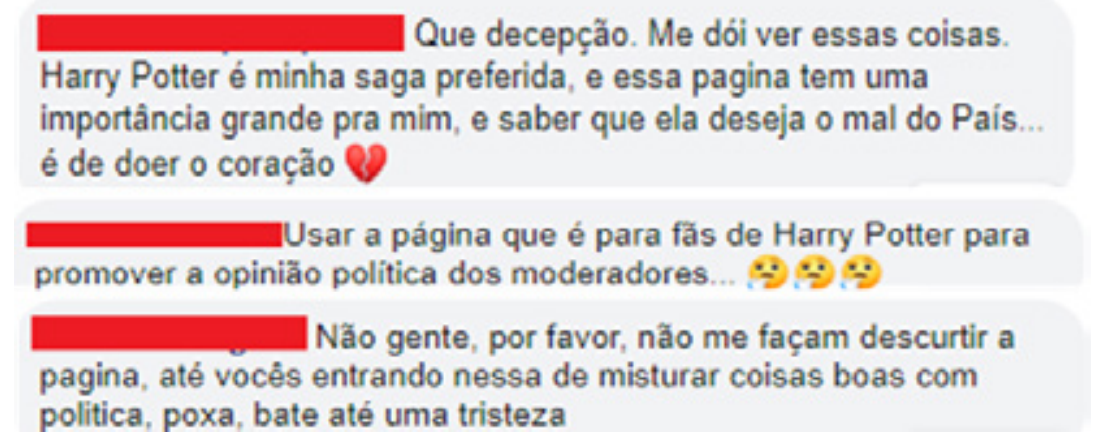

Fonte: Aquele-Que-Não-Deve-Ser-Votado ${ }^{17}$

Mais do que insultos, nesses comentários coletados, a estratégia discursiva reinante é a da ameaça. Isso não significa que outros comentários não utilizem insultos como manifestação argumentativa. Em geral, os insultos se voltam ao PT. Como, neste artigo,

172 de outubro 2018. Disponível em: https://www.facebook.com/Potterish/. Acesso em: 06 jan. 2019. 
- Voldemort e Bolsonaro: diálogo entre arte, mídia e política

o objetivo não se volta à relação entre Bolsonaro e o antipetismo, mas entre Voldemort e Bolsonaro, comentários selecionados representam o tom da voz dominante referente à temática aqui explorada. Além da ameaça, o lamento também impera, como pôde ser visto na Figura 3.

Hobsbawm e Santarrita (1995), ao discorrerem sobre o fascismo, destacam que se trata de um movimento de superioridade, pautado no nacionalismo, no anticomunismo, na mobilização de massas e na defesa de valores "tradicionais". Para os historiadores, é um movimento que se opõe à emancipação e à hiperculturalidade (HAN, 2019) hipermoderna (LIPOVETSKY, 2004). O discurso dos representantes fascistas assume uma lógica conservadora, como estudam Diwan (2007) e Black (2003).

Os fãs respondem ao manifesto do Potterish porque ele se volta à temática central da saga e utiliza o vilão em analogia a um dos candidatos à presidência, no período mais intenso de campanha (o segundo turno das eleições de 2018). Trata-se, o manifesto, de um texto opinativo comparativo (Voldemort e Bolsonaro). A própria capa revela o posicionamento do portal ao integrar os sujeitos, num rosto só, com uma montagem em escala cromática temática de cores frias, trabalhadas de maneira análoga (na mesma região cromática), monocromática (com variações tonais das mesmas cores, em escalas mais claras ou mais escuras, mais agudas ou mais graves, mais intensas e brilhantes ou mais relaxantes e opacas, misturadas) e personalizada na paleta gradiente de verde e azul que, na saga, caracterizam as sombras (cinzas e pretas) ${ }^{18}$ e semiotizam o "mal", representado por Voldemort, como pode ser visto nos fotogramas 2, 3, 4, 5, 6 e 7, produzidos ${ }^{19}$ a partir do cartaz (fotograma 1) da Figura 4:

\footnotetext{
18 Para se aprofundar na relação da saga romanesca e fílmica, ler Paula e Siani (2021, no prelo). As autoras demonstram, em sua análise, o quanto, já na abertura dos filmes, conforme os temas ficam mais complexos, "adultos" e o discurso eugenista do nazifascismo se estabelece, com a volta e o fortalecimento de Voldemort, mais sombrias e escuras se tornam as obras fílmicas, com exploração da escala cromática de tons de verde, azul, cinza e preto, acompanhadas pelas mortes e magias "proibidas" (por se tratarem de maldições), com perseguições e torturas, a ponto de as próprias personagens verbalizarem que "São tempos sombrios", "igualzinho a outra vez", remetendo, junto a outros tantos fatos do enredo, a uma segunda guerra bruxa, em alusão à segunda guerra mundial.

19 Para a extração de cores e a montagem das escalas, foram utilizados o Adobe Color, o Canvas e o Colordot. A interpretação se pautou em Guimarães (2001), Goethe (2013), Haynes (2008), Heller (2013) e Kandinsky (1970).
} 
Figura 4. Capa do Manifesto do Potterish e sua escala cromática

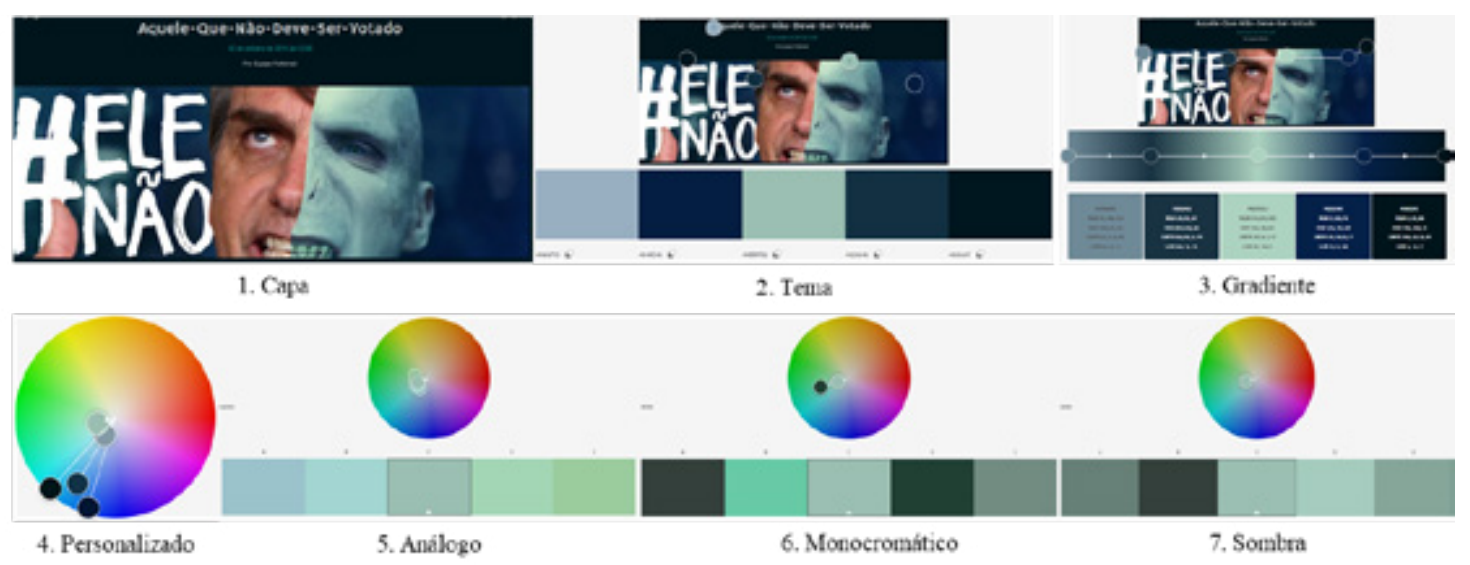

Fonte: Fotograma 1 - Aquele-Que-Não-Deve-Ser-Votado ${ }^{20}$ e Fotogramas 2 a 7 - Produção das autoras

As cores, como outros elementos, de todas as dimensões (construção verbal, ponto, linha, formas, suas direções, foco, ângulo, cenografia, figurino, trilha sonora, vocalidade, entonação, tonalidades, tons, silêncio, pausa, ritmo, entre outros), têm sentidos variados que, no enunciado, materializam sentidos em integração com o todo unitário arquitetônico discursivo e não podem ser analisados isoladamente. Em $H P$, azul e verde constroem, junto com outros elementos, o sentido emotivo-volitivo-ideológico de paralisia, medo, terror, depressão, melancolia, tristeza, aflição, tensão, mistério sinistro e, nesse sentido, liga-se, em seus vários tons e matizes, com o efeito de tempo-espaçosujeito sombrio.

O cartaz-montagem elaborado e postado pelo Potterish se apropria dessa significação composicional fílmica e a integra (não apenas pela junção das meias faces de Bolsonaro e Voldemort, nessa ordem e centralizados, em primeiro plano no enunciado), mas para transpô-la, da arte à vida, especificamente, à política e ao político negado, pois a única inscrição que se sobrepõe, ao lado da metade da face de Bolsonaro, como que a empurrá-la e, tridimensionalmente, acima dela, em primeiríssimo plano, em branco (paz e união de todas as cores, vozes e sujeitos), é a hashtag de um movimento expressivo, sobre a qual será melhor dito adiante, contra esse sujeito (Bolsonaro) e os valores que ele representa, a "\#ELENÃO" (assim, em caixa alta e verticalizada). O verbal expressa o posicionamento do portal, que se coloca junto ao movimento "\#EleNão", como rival do vilão/mal Bolsonaro-Voldemort, já não mais dois e sim dois-em-um, um-em-dois, vida-

202 de outubro 2018. Disponível em: https://www.facebook.com/Potterish/. Acesso em: 06 jan. 2019. 
- Voldemort e Bolsonaro: diálogo entre arte, mídia e política

em-arte, arte-em-vida. Tudo alinhavado pela ambientação escura, sombria, fria, verdeazulada "Sonserina"21.

Outra apropriação, em trocadilho, presente no cartaz, ocorre com uma das expressões que nomeiam Voldemort: "Aquele-Que-Não-Deve-Ser-Nomeado" passa a ser "Aquele-Que-Não-Deve-Ser-Votado", uma vez que nomeado Bolsonaro já não era. Não usar o seu nome nas redes sociais foi uma estratégia da oposição para tentar driblar os boots e os algoritmos, a fim de restringir o alcance de sua campanha publicitário-política, calcada em fake news. O candidato passou a ser chamado, então, pelo pronome de terceira pessoa do singular (a não-pessoa do discurso, segundo Benveniste (1989, 1991), uma vez que não tem voz, mas é o assunto sobre o qual os sujeitos do discurso eu-tu/outro falam): Ele, o que, por um lado, dribla sua campanha e, por outro, também o fortalece, pois é tão conhecido que nem precisa ser nomeado. Como diria Fiorin (2016), são muitas "as astúcias da enunciação".

Diferente de Voldemort, não nomeado por medo, Bolsonaro não era nomeado como forma (ainda que ambígua) de combate/enfrentamento. A troca de "nomeado" por "votado" coloca, no plano verbo-vocal, Bolsonaro no lugar de Voldemort, o que confirma, no plano visual, a união dos dois sujeitos em um, como o Jano Bifronte, representado pela unidade das caras-metades de Voldemort e Bolsonaro.

A hashtag movimentou uma página desenvolvida por e para mulheres, chamada "Mulheres contra Bolsonaro", que viralizou e se tornou um dos maiores movimentos de oposição à eleição de Jair. A "\#EleNão" popularizou e empoderou a voz antagônica das mulheres que se sentiram ofendidas com os insultos e o tratamento a elas direcionados pelo então candidato. Nomear e votar, por similitude, mais do que aproximar e identificar os sujeitos, passaram a constituir o valor de resistência às vozes sociais que aqueles sujeitos representavam/representam. Ato de linguagem que revela posicionamento e pretende funcionar na prática, como um outro tipo de campanha, surgida na infraestrutura, como força centrífuga cotidiana popular. Uma força centrífuga ou centrípeta não atua o tempo inteiro e nem da mesma maneira e com o mesmo vigor. Isso não significa que, em determinado contexto, de forma situada, determinadas vozes opositoras também não possam ser resistência (no caso à eleição de Bolsonaro). Esse é o caso do movimento \#EleNão, com sua participação ativa naquele momento específico da eleição.

\footnotetext{
21 Sonserina é uma das casas que abriga os alunos em Hogwarts. Sua cor é verde e prata/cinza. Seu símbolo é uma serpente - falsidade e sabedoria, ao mesmo tempo. Voldemort foi dessa casa em seu tempo de escola. A casa fica nas masmorras do castelo, ou seja, um dos piores lugares, pois um cárcere subterrâneo, descrito por Rowling nos livros como úmido e frio, hierarquicamente abaixo de todos. Os bruxos selecionados para viverem nessa casa são inteligentes e preciosos, mas fazem tudo por poder, são egoístas e excêntricos. Mal compreendidos, muitas vezes, pois sinistros e misteriosos. Salazar Sonserina é o bruxo que a representa e, dentre as características negativas pregadas por ele aos alunos, destaca-se a ambição e a valoração da "pureza" da raça.
} 
O manifesto circulou no portal e no Facebook, porém ganhou maior repercussão no último (seguido, até 02/10/2020, por 386.279 pessoas e, dessas, 382.016 fãs curtiram a postagem). O enunciado, postado em 02/10/2018, tem a legenda "Aos fãs apolíticos sentimos informar, Harry Potter é pura política". Esse manifesto repercutiu bastante entre os fãs. Em 02/10/2020, dois anos depois, a publicação contava com 5,8 mil reações, 1,2 mil comentários e 2 mil compartilhamentos. A autoria é de um dos editores da equipe. O manifesto contextualiza as manifestações ocorridas no período eleitoral e surgiu, segundo consta na página, em razão da necessidade de combater o discurso de ódio propagado por Bolsonaro e seus seguidores. Juntamente ao texto verbo-vocal há a imagem do cartaz com a frase "Quando Voldemort é candidato à presidência, nós precisamos de uma nação de Hermiones! \#EleNão", o que remete, por analogia, às mulheres adeptas ao movimento, também criado por mulheres.

Ao longo do texto são citados movimentos de resistência existentes na saga: a "Ordem da Fênix" (movimento político de resistência a Voldemort e aos Comensais da Morte); a "Armada de Dumbledore" (movimento instituído em Hogwarts em um momento no qual os alunos foram impedidos pelo Ministério de praticar magia defensiva. Com ele, os alunos, secretamente, praticam magia, a fim de se defender e sobreviver na guerra que se aproxima); e o "Fundo de Apoio à Libertação dos Elfos Domésticos" (movimento fundado por Hermione, a fim de colocar um fim no regime escravocrata dos Elfos Domésticos). O editorial relembra, por fim, a importância de lutar e de defender a democracia em um momento frágil, no qual a liberdade é cada vez mais escassa e os insultos, a tortura e o preconceito ganham mais força:

Aos fãs apolíticos, sentimos informar: a série Harry Potter é puramente política. A Ordem da Fênix, como organização de luta e resistência, é política. A Armada de Dumbledore, pondo-se à frente da tirania de Dolores Umbridge, é política. Dumbledore e Newt se unindo para lutar contra o fascismo de Grindelwald, que pregava a supremacia bruxa sobre trouxas, é política. O Fundo de Apoio à Libertação dos Elfos Domésticos (F.A.L.E.), tão ridicularizado e incompreendido, é luta pelos direitos das minorias, é resistência e é política. J. K. Rowling se preocupou em estabelecer instâncias claras de poder no mundo bruxo. O Ministério da Magia é a evidência mais óbvia de como é possível utilizarse do poder para fazer mal àqueles que deveriam ser, em primeiro lugar, defendidos. A lição nos parece clara: a democracia é uma entidade frágil com a qual não se brinca, que deve ser alimentada todos os dias de modo a se fortalecer. (POTTERISH, 2018). 
- Voldemort e Bolsonaro: diálogo entre arte, mídia e política

A palavra (no sentido alargado utilizado por Volochínov, 2013) reverberada por Voldemort e Bolsonaro, aproxima-os pela temática da "pureza" (DIWAN, 2007) nazifascista, materializada pelos atos de linguagem que semiotizam a significação dos eventos por cada um deles defendidos, nas esferas literária e política. Um desses atos que aproxima os dois sujeitos é a manipulação das mídias contra aqueles que assumem como seus "inimigos", considerados "impuros". Contra esses atos é que o Potterish se posiciona. O discurso dessas personagens compõe a consciência de dado grupo, que se autodesigna "conversador", "nacionalista" e "de direita", em oposição a outros, em especial, ao de "esquerda". O sujeito sempre se posiciona, de maneira responsiva e responsável, em embate, na arena discursiva.

No enunciado, os valores absorvidos pela consciência são revelados. Nesse sentido, a consciência humana é, ao mesmo tempo, individual e social, pois os signos absorvidos pertencem ao solo social. O conservadorismo e o autoritarismo marcam diversos governos ao longo da história. Neste estudo, foi possível visualizar o quanto a arte semiotiza a vida, bem como o quanto governos de direita, simbolizados por Voldemort e Bolsonaro, possuem elementos em comum: políticas de censura a materiais que fazem com que as pessoas pensem, punição de professores que incentivem a criticidade e o questionamento, tortura ou perseguição de minorias e daqueles que discordem de suas práticas, blasfêmias sobre sujeitos considerados "rivais", transformados em sujeitos "perigosos", entre outras.

\section{Considerações finais}

Este artigo revelou que a política ficcional de Harry Potter ganha força no Brasil contemporâneo e que o discurso do vilão da saga se assemelha ao do presidente, pela discriminação aos considerados "impuros" (feministas, pessoas de etnias não-brancas, LGBTQIA+, dentre outros considerados "sangue ruim").

Ao se considerar a noção dialética de infra e superestrutura, explicitada no ensaio O trabalho Alienado, de Marx (2007), pode-se dizer que o discurso de HP se cristaliza na superestrutura, legitima-se com as forças centrípetas (pelos seus seguidores, que, no cotidiano, incorporam o signo "sangue ruim" e ofendem aqueles que se opõem ao governo) e se ressignifica, na infraestrutura, com as forças centrífugas, na vida cotidiana, num movimento que faz com que os fãs se posicionem, em reação responsivo-responsável.

A troca de sentidos, mediada pelo contato do sujeito (eu) com os seus outros na interação, corresponde a domínios diferentes de valores refletidos e refratados em enunciados que materializam vozes sociais em embate, como ocorreu com os fãs de $H P$ 
no Potterish. Volóchinov (2017, p. 205), ao se referir ao enunciado e aos sujeitos como representantes socais, afirma que

[...] o enunciado se forma entre dois indivíduos socialmente organizados, e, na ausência de um interlocutor real, ele é ocupado, por assim dizer, pela imagem do representante médio daquele grupo social ao qual o falante pertence. A palavra é orientada para o interlocutor, ou seja, é orientada para quem é esse interlocutor: se ele é integrante ou não do mesmo grupo social, se ele se encontra em uma posição superior ou inferior em relação ao interlocutor (em termos hierárquicos), se ele tem ou não laços sociais com o falante (pai, irmão, marido etc.). Não pode haver um interlocutor abstrato, por assim dizer, isolado.

Os sujeitos semiotizam as vozes de grupos sociais, em épocas e espaços distintos. Nesse sentido é que Voldemort e Bolsonaro semiotizam, na arte e na vida, junto com seus seguidores, a voz social do nazifascismo enquanto o Potterish, em seu manifesto, posiciona-se, em oposição a essa voz, como resistência e os fãs da página entram em embate responsivo e responsável ao coadunarem com uma dessas vozes.

No plano da arte, tal qual Bolsonaro, o discurso e as práticas de Voldemort são marcados pela ideologia da "pureza". Os dois sujeitos se dedicam às suas forças, na figura dos seus subordinados (comensais da morte e bolsominions), para censurar, perseguir e cercear a liberdade daqueles que não concordam com os seus valores e atos, marcados pelo ódio às minorias, pela manipulação da mídia, pela desvalorização da educação e da pesquisa, pela força, simbólica e física, tanto na comunidade mágica-bruxa quanto na sociedade brasileira.

Os discursos de Voldemort, na arte e de Bolsonaro, na vida, são marcados por alguns elementos recorrentes, característicos de governos autoritários e que combatem, de formas diversas, aqueles que os contestam por meio da repressão e da opressão. A ambição pelo poder, a construção de um exército de subordinados que disseminam o ódio e a violência, a sensação de medo e impotência, o cerceamento da liberdade, a censura nas escolas, os desaparecimentos, os exílios e a manipulação das mídias são elementos que aproximam a arte da vida, ainda que com acabamentos arquitetônicos distintos.

Os discursos de Voldemort e Bolsonaro, marcados pela ideologia da "superioridade", constituem esses sujeitos e as vozes sociais nazifascistas por meio da linguagem. O uso da propaganda, nas mídias, na arte e na vida, colabora para com a vilanização daqueles que contestam esses sujeitos e seus governos. As mídias instauram 
- Voldemort e Bolsonaro: diálogo entre arte, mídia e política

o medo e a devoção da população frente àquele que os governa e manipulam fatos com mentiras (as fake news). É comum que governos autoritários tenham seu exército de súditos fiéis (amparados por parte da Igreja), assim como uma marca identitária que os compõe e representa sua postura política (o nacionalismo verde-e-amarelo, no caso de Bolsonaro, simbolizado pela camiseta da seleção, a bandeira do Brasil e o seu slogan de campanha; e a marca negra de Voldemort).

Este artigo refletiu, fundamentado nos estudos bakhtinianos, sobre as simetrias entre Voldemort e Bolsonaro, entendidos como sujeitos da arte e da vida, representantes de vozes e valores nazifascistas, em cotejo com os comentários mais repercutidos no Facebook sobre essa relação, produzidos pelos fãs em resposta ao manifesto do Potterish contra Bolsonaro no período eleitoral de 2018. Parte dos fãs posicionou-se a favor do manifesto, calcada em eventos da obra e vendo os insultos proferidos e as práticas propostas pelo então candidato como perigosas e, portanto, a serem combatidas; enquanto outra parte se autodenominou "apolítica" e questionou a relação arte e política, recusando-se à discussão com uma estratégia discursiva marcada por ameaças ("descurtir" a página) e lamentos (seja em nome de uma "neutralidade" inexistente, seja por discordarem do Potterish e serem eleitores de Bolsonaro).

Pensar na relação arte e vida a partir das figuras de Voldemort e Bolsonaro para refletir sobre a ação de governos autoritários por meio do embate de vozes dos fãs da saga revelou vozes, valores e práticas sociais, além de demonstrar a importância do papel da arte e das mídias para a constituição sócio-político-cultural e a formação das consciências humanas.

\section{Referências}

ADOBE COLOR WHEEL. Adobe Color. Disponível em https://color.adobe.com/pt/ create/color-wheel. Acesso em: 27 set. 2020.

ALMEIDA, S. Racismo estrutural (Feminismos plurais). São Paulo: Pólen Livros, 2019.

BAKHTIN, M. O homem ao espelho - Apontamentos dos anos 1940. São Carlos: Pedro \& João, 2019.

BAKHTIN, M. M. Problemas da poética de Dostoiévski. Rio de Janeiro: Forense Universitária, 2018. 
BAKHTIN, M. Notas sobre literatura, cultura e ciências humanas. Rio de Janeiro: 34, 2017.

BAKHTIN, M. M. Os gêneros do discurso. Rio de Janeiro: 34, 2016.

BAKHTIN, M. M. Questões de literatura e de estética: a teoria do romance. São Paulo: Hucitec, 2014.

BAKHTIN, M. M. Estética da criação verbal. São Paulo: WMF Martins Fontes, 2011.

BAKHTIN, M. M. Para uma filosofia do ato responsável. São Carlos: Pedro \& João, 2010.

BAKHTIN, M.; VOLOCHÍNOV, V. A palavra própria e a palavra outra na sintaxe da enunciação. São Carlos: Pedro \& João, 2019.

BARISSA, A. B. M. Por e para fãs: uma análise dialógica de Severo Snape em uma produção transmidiática. 2019. Dissertação (Mestrado em Linguística e Língua Portuguesa) - Faculdade de Ciências e Letras, Universidade Estadual Paulista "Júlio de Mesquita Filho", Araraquara, 2019 (Mimeo).

BENVENISTE, E. Estrutura das relações de pessoa no verbo. In: BENVENISTE, E. Problemas de Lingüística Geral I. São Paulo: Pontes, 1991a.

BENVENISTE, E. A natureza dos pronomes. In: BENVENISTE, E. Problemas de Lingüística Geral I. São Paulo: Pontes, 1991b.

BENVENISTE, E. Da subjetividade na linguagem. In: BENVENISTE, E. Problemas de Lingüística Geral I. São Paulo: Pontes, 1991c.

BENVENISTE, E. O aparelho formal da enunciação. In: BENVENISTE, E. Problemas de Lingüística Geral II. São Paulo: Pontes, 1989.

BLACK, E. A guerra contra os fracos: a eugenia e a campanha norte-americana para criar uma raça superior. São Paulo: A Girafa, 2003.

CANVA COLOR PALETTE GENERATOR. Canva. Disponível em: https://www.canva.com/ colors/color-palette-generator/. Acesso em: 27 set. 2020. 
- Voldemort e Bolsonaro: diálogo entre arte, mídia e política

CECATTO, I. O Voldemort da vida real, 2009. Disponível em: https://potterish.com/ovoldemort-da-vida-real/. Acesso em: 04 maio 2020.

CHAUÍ, M. Manifestações ideológicas do autoritarismo brasileiro. Belo Horizonte: Autêntica, 2013.

CHAUÍ, M. Conformismo e resistência. Belo Horizonte: Autêntica, 2014.

COLORDOT HAIL PIXEL. Colordot. Disponível em: https://color.hailpixel.com/. Acesso em: 27 set. 2020.

DIWAN, P. Raça pura: uma história da eugenia no Brasil e no mundo. São Paulo: Contexto, 2007.

FIORIN, J. L. As astúcias da enunciação: as categorias de pessoa, espaço e tempo. São Paulo: Contexto, 2016.

GOETHE, J. W. Doutrina das Cores. São Paulo: Nova Alexandria, 2013.

GUIMARÃES, L. A cor como informação: a construção biofísica, linguística e cultural da simbologia das cores. São Paulo: Annablume, 2001.

HAN, B-C. Hiperculturalidade: Cultura e Globalização. Rio de Janeiro: Vozes, 2019.

HAYNES, D. J. Bakhtin and the visual arts. Nova lorque: Cambridge, 2008.

HELLER, E. A psicologia das cores: como as cores afetam a emoção e a razão. São Paulo: Gustabo Gili, 2013.

HOBSBAWM, E.; SANTARRITA, M. Era dos Extremos: o breve século XX: 1914-1991. São Paulo: Companhia das Letras, 1995.

JENKINS, H. Convergence Culture: Where Old and New Media Collide. Nova lorque: NYU Pres 2006.

KANDINSKY, W. Ponto, Linha, Plano - contribuição para análise dos elementos picturais. Lisboa: Edições 70, 1970. 
LIPOVETSKY, G. Os tempos hipermodernos. São Paulo: Barcarolla, 2004.

MACHADO, F. V. K.; GONZATTI, C. Harry Potter e aquele-que-não-deve-ser-votado: imaginação cívica, ativismo de fãs e fascismo eterno em redes digitais do jornalismo de cultura pop. C\&S, v. 41, n. 2, p. 373-403, 2019.

MARX, K. O trabalho alienado. Manuscritos Econômico-Filosóficos. HTML 2007. Disponível em: https://www.marxists.org/portugues/marx/1844/manuscritos/index. htm. Acesso em: 27 set. 2020.

MBEMBE, A. Necropolítica. Arte \& Ensaios, Rio de Janeiro, n. 32, p. 122-151, dez. 2016.

MEDVIÉDEV, P. N. O método formal nos estudos literários: introdução crítica a uma poética sociológica. São Paulo: Contexto, 2012.

OLIVEIRA, N. R. de. A febre amarela "minions": uma análise bakhtiniana. 2020.

Dissertação (Mestrado em Linguística e Língua Portuguesa) - Faculdade de Ciências e Letras, Universidade Estadual Paulista "Júlio de Mesquita Filho", Araraquara, 2020 (Mimeo).

PAULA, L. de. O enunciado verbivocovisual de animação - a valoração do "amor verdadeiro" Disney - uma análise de Frozen. In: FERNANDES JR., A.; STAFUZZA, G. B. (org.). Discursividades Contemporâneas: política, corpo, diálogo. Série Estudos da Linguagem. Campinas: Mercado de Letras, 2017. p. 287-314.

PAULA, L. de; FIGUEIREDO, M. H. de; PAULA, S. L. de. O Marxismo do/no Círculo. In: STAFUZZA, G. B (org.). Slovo - o Círculo de Bakhtin no contexto dos estudos discursivos. Curitiba: Appris, 2011, p. 79-98.

PAULA, L. de; LOPES, A. C. S. A eugenia de Bolsonaro: leitura bakhtiniana de um projeto de holocausto à brasileira. Linguasagem, São Carlos, Dossiê Discurso em tempos de pandemia, v. 35, p. 35-76, set./2020. Disponível em: http://www.linguasagem.ufscar.br/ index.php/linguasagem/article/view/769. Acesso em: 10 out. 2020.

PAULA, L. de; LUCIANO, J. A. R. A filosofia da linguagem bakhtiniana e sua tridimensionalidade verbivocovisual. Estudos Linguísticos (São Paulo), p. 706-722, jun. 2020a. DOI: https://doi.org/10.21165/el.v49i2.2691. Disponível em: https://revistas.gel. org.br/estudos-linguisticos/article/view/2691/1713. Acesso em: 16 set. 2020a. 
- Voldemort e Bolsonaro: diálogo entre arte, mídia e política

PAULA, L. de; LUCIANO, J. A. R. Filosofia da Linguagem Bakhtiniana: concepção verbivocovisual. Revista Diálogos (RevDia), Intergrupos: estudos bakhtinianos, v. 8, n. 3, p. 111-131, 2020b. Disponível em: https://periodicoscientificos.ufmt.br/ojs/index.php/ revdia/article/view/10039. Acesso em: 28 nov. 2020b.

PAULA, L. de; LUCIANO, J. A. R. A tridimensionalidade verbivocovisual da linguagem bakhtiniana. Linha D’Água (On-line), São Paulo, v. 33, n. 3, p. 105-134, set.-dez. 2020c. DOI: https://doi.org/10.11606/issn.2236-4242.v33i3p105-134. Disponível em: https:// www.revistas.usp.br/linhadagua/article/view/171296. Acesso em: 28 nov. 2020c.

PAULA, L. de; LUCIANO, J. A. R. Recepções do pensamento bakhtiniano no ocidente: a verbivocovisualidade no Brasil. In: BUTTURI JÚNIOR, A.; BRAGA, S.; SOARES, T. B. (org.). No Campo Discursivo: teoria e análise. Campinas: Pontes, 2020d. p. 133-166.

PAULA, L. de; LUCIANO, J. A. R. Dialogismo verbivocovisual: uma proposta bakhtiniana. Polifonia, 2020e (no prelo).

PAULA, L. de; OLIVEIRA, F. A. A. de. O signo "resistência" nas eleições presidenciais de 2018 no Brasil. Entreletras (Araguaína), v. 10, n. 2, p. 350-371, jul./dez. 2019. DOI: https:// doi.org/10.20873/uft.2179-3948.2019v10n2p350. Disponível em https://sistemas.uft. edu.br/periodicos/index.php/entreletras/article/view/6999. Acesso em: 10 out. 2020.

PAULA, L. de; OLIVEIRA, F. A. A de. A "nação" nas redes sociais e na política brasileira. Entrepalavras, Fortaleza, [S.I.], v. 10, n. 3, out. 2020. DOI: http://dx.doi. org/10.22168/2237-6321-31858. Disponível em: http://www.entrepalavras.ufc.br/ revista/index.php/Revista/article/view/1858. Acesso em: 29 nov. 2020.

PAULA, L. de; SERNI, N. M. A vida na arte: a verbivocovisualidade do gênero filme musical. Raído, Dourados, v. 11, n. 25, p. 178-201, jul. 2017. DOI: https://doi. org/10.30612/raido.v11i25.6507. Disponível em: https://ojs.ufgd.edu.br/index.php/ Raido/article/view/6507. Acesso em: 10 out. 2020.

PAULA, L. de; SIANI, A. C. Filme e Romance: Harry Potter e O Cálice de Fogo. In: DIONÍSIO, M. de L.; REMENCHE, M. de L. R. (org.). Ler e Escrever na Cibercultura: concepções e práticas. Campinas: Pontes, 2021 (no prelo). 
PAULA, L. de; SIANI, A. C. Uma análise bakhtiniana da necropolítica brasileira em tempos de pandemia. Revista da Abralin, 2020a (no prelo).

PAULA, L. de; SIANI, A. C. O sangue puro em Harry Potter e seus ecos dialógicos eugênicos. Calidoscópio, v. 18, n. 3, p. 590-615, set./dez. 2020b. Disponível em: http:// revistas.unisinos.br/index.php/calidoscopio/article/view/cld.2020.183.06. Acesso em: 08 dez. $2020 b$.

PAULA, L. de; SIANI, A. C. Gênero, raça e classe em Harry Potter: a constituição dialógica de Hermione Granger e Belatriz Lestrange. Cadernos Discursivos, Catalão-GO, v. 1, n. 1, p. 47-74, 2019. Disponível em: https://bit.ly/3IVqSke. Acesso em: 08 dez. 2020.

PONZIO, A. Encontros de palavras. O outro no discurso. São Carlos: Pedro \& João, 2018. PONZIO, A. A revolução bakhtiniana. São Paulo: Contexto, 2016.

PONZIO, A. Procurando uma Palavra Outra. São Carlos: Pedro \& João, 2010.

ROWLING, J. K. Harry Potter e a Pedra Filosofal. Rio de Janeiro: Editora Rocco, 2015a.

ROWLING, J. K. Harry Potter e a Câmara Secreta. Rio de Janeiro: Editora Rocco, 2015b.

ROWLING, J. K. Harry Potter e o Prisioneiro de Azkaban. Rio de Janeiro: Editora Rocco, 2015c.

ROWLING, J. K. Harry Potter e o Cálice de Fogo. Rio de Janeiro: Editora Rocco, 2015d.

ROWLING, J. K. Harry Potter e a Ordem da Fênix. Rio de Janeiro: Editora Rocco, 2015e.

ROWLING, J. K. Harry Potter e o Enigma do Príncipe. Rio de Janeiro: Editora Rocco, $2015 f$.

ROWLING, J. K. Harry Potter e as Relíquias da Morte. Rio de Janeiro: Editora Rocco, 2015g.

SCHWARCZ, L. M. Nem preto nem branco, muito pelo contrário. Rio de Janeiro: Claro Enigma, 2013. 
- Voldemort e Bolsonaro: diálogo entre arte, mídia e política

SCHWARCZ, L. M. O espetáculo das raças. Rio de Janeiro: Companhia das Letras, 1993.

VOLÓCHINOV, V. Palavra na vida e a palavra na poesia: ensaios, artigos, resenhas e poemas. Rio de Janeiro: 34, 2019.

VOLÓCHINOV, V. Marxismo e filosofia da linguagem: problemas fundamentais do método sociológico na ciência da linguagem. Rio de Janeiro: 34, 2017.

VOLÓCHINOV, V. A construção da enunciação e outros ensaios. São Carlos: Pedro \& João, 2013.

WARNER BROS. Harry Potter e o Cálice de Fogo. Direção de Mike Newll, 157 min., 2005.

WARNER BROS. Harry Potter e as Relíquias da Morte Parte II. Direção de David Yates, 130 min., 2011.

WARNER BROS. Harry Potter e as Relíquias da Morte Parte I. Direção de David Yates, 146 min., 2010.

WARNER BROS. Harry Potter e o Enigma do Príncipe. Direção de David Yates, 153 min., 2009.

WARNER BROS. Harry Potter e a Ordem da Fênix. Direção de David Yates, 138 min., 2007.

WARNER BROS. Harry Potter e o Prisioneiro de Azkaban. Direção de Alfonso Cuarón, $142 \min ., 2004$.

WARNER BROS. Harry Potter e a Câmara Secreta. Direção de Chris Columbus, 174 min., 2002.

WARNER BROS. Harry Potter e a Pedra Filosofal. Direção de Chris Columbus, 159 min., 2001. 
COMO CITAR ESTE ARTIGO: PAULA, Luciane de; MOURA, Giovana Cristina de. Voldemort e Bolsonaro: diálogo entre arte, mídia e política. Revista do GEL, v. 18, n. 1, p. 169-203, 2021. Disponível em: https://revistadogel.gel.org.br/

Submetido em: 07/12/2020 | Aceito em: 23/01/2021. 